\title{
FOREST RESOURCES UTILIZATION VALUE OF THE COMMUNITIES LIVING IN AND AROUND GUNUNG LUMUT PROTECTION FOREST, EAST KALIMANTAN
}

\author{
Murniati $^{1,2}$, Michael Padmanaba ${ }^{3}$ and Imam Basuki ${ }^{3}$
}

\begin{abstract}
Forest of Gunung Lumut in Pasir District, East Kalimantan was appointed as a Protection Forest since 1983. The forest is surrounded by 15 villages and one settlement lies inside. Communities in those villages depend on the forest resources mainly for non timber forest products (NTFPs). This study focused on the utilization and conservation of the protection forest resources by the community living in and around the forest. The study was conducted in two settlements, which located in and outside (near) the protection forest area, namely Mului sub village and Rantau Layung village. The data collection was undertaken through general field observations, focused group discussions, and personal interviews. Mului people, who live inside the Gunung Lumut Protection Forest (GLPF) area, had higher positive perception on forest and conservation $(80.3 \%)$ as well as on legal status of GLPF (74.2\%) than those in Rantau Layung people $(76 \%$ and $53.3 \%$, respectively), who live outside the protection area. Utilization value of the GLPF resources, mainly NTFPs, by the communities is significant, reaching seven to eight millions rupiah per household per year. Plant resources utilized was two to three times higher than animal resources. However, most of the NTFPs gathered from forest area were sold as raw materials, and no post harvesting technology applied to gain an added value of the NTF products.
\end{abstract}

Keywords: Biodiversity, non timber forest products, participatory, gathering and hunting

\section{INTRODUCTION}

\section{A. Background}

Forest area of Gunung Lumut was reserved as a protection forest through the Forestry Minister Decree No. 24/Kpts/Um/1983. Previously, the area had been a production forest since the beginning of 1970 s and used as a concession area managed by PT. Telaga Mas. Gunung Lumut Protection Forest (GLPF)

Forest and Nature Conservation Research and Development Center, J1. Gunung Batu No.5, P.O. Box 165, Bogor 16610, Indonesia

2 Corresponding Author. E-mail: murniati@forda.org

3 Centre for International Forestry Research, Jl. CIFOR Situ Gede, P.O. Box 0113 BOCBD, Bogor 16115, Indonesia 
lies between $116^{\circ} 02^{\prime} 57^{\prime \prime}$ and $116^{\circ} 50^{\prime} 41^{\prime \prime}$ East longitude, and $01^{\circ} 19^{\prime} 08^{\prime \prime}$ and $01^{\circ} 49^{\prime} 33^{\prime \prime}$ South latitude covering an area of 35,350 ha. It stretches from the north to the south about $56.3 \mathrm{~km}$ in length and $8.3 \mathrm{~km}$ in width, surrounded by 15 villages and one settlement is located inside the protection forest, as shown in the GLPF map (Anonymous, 2005). Saragih (2004) reported that there are 74,037 people living in and around the protection area who are highly dependent on its forest resources mainly non-timber forest products (NTFPs), as well as environmental services. Administratively, GLPF belongs to Pasir District and consists of four sub districts i.e. Long Kali, Muara Komam, Long Ikis, and Batu Sopang.

The GLPF is mainly covered by dipterocarp lowland forest, part of which is dominated by the trees of meranti (Shorea spp.) and kapur (Dryobalanops lanceolata). From about one third of the protection area surveyed in 2004 $(12,800 \mathrm{ha})$, the forested area is around $90 \%$ and the remaining $10 \%$ is covered by shrubs (UPTD Planologi Kehutanan Balikpapan, 2004). Another source stated that currently only about $60 \%$ of the forest is still in pristine condition with a complete flora and fauna (Anonymous, 2005).

Buffer zones of the GLPF that serve as production and limited production forest areas has been unfortunately degraded, where only small number of big diameter trees can be found (UPTD Planologi Kehutanan Balikpapan, 2004). These buffer zones are inhabited by thousands of forest-dependent people. Based on Forest Land Use Agreement (Tata Guna Hutan Kesepakatan) and Regional Spatial Planning of Pasir District, the buffer zones of GLPF is classified as a forestry plantation area (Kawasan Budidaya Kehutanan).

Although forest in Gunung Lumut has been designated as a protection area, logging activities have continued and even worsened in the last five years when large number of small concessions (IUPHHK: Ijin Usaba Pemanfaatan Hasil Hutan Kayu) around the protection forest were granted by Head of the District (Bupati). Fortunately, the issuing of these IUPHHK has been put to an end in compliance with the Forestry Minister Decree No. 541/Kpts-II/2002. Recently, the protection forest is still under heavy pressure from various activities. Several big forest concessions (HPH: Hak Pengusabaan Hutan) still operate around the protection forest area. In addition, forest encroachments are still taking place around the protection area.

\section{B. Objectives}

The study focused on the interaction between communities and surrounding natural resources, including social and economic conditions of the communities living in and around the protection forest. 
Objectives of the study were: (1) to obtain data on socio-cultural and socio-economy condition of the communities including household income and expenditure pattern; (2) to identify landscape type, natural resources, and local utilization; and (3) to estimate the value of the natural resources being used by the local communities

\section{MATERIALS AND METHODS}

\section{A. Locations and Time}

The study was conducted in two settlement sites located around and within the GLPF i.e. Rantau Layung Village and Mului sub Village (Figure 1). Both sites belong to Pasir District, East Kalimantan Province. Rantau Layung Village is administratively managed by Batu Sopang sub District, located about 150 $\mathrm{km}$ from Tanah Grogot (Capital of Pasir District) and can be reached only by four wheel drive vehicle taking four hours from Tanah Grogot or six hours from Balikpapan City. River and small road are the main transportation infrastructures available in Rantau Layung. To travel from Rantau Layung to Batu Kajang, capital of Batu Sopang sub District, villager can only use motor boat moving through Kasunge River for six hours. The small road, built in 2003, is the only ground access from Rantau Layung to the main road (actually logging road). The total area of Rantau Layung village is 18,913 ha. Meanwhile, Mului is part of Swan Slutung village and belongs to Muara Komam Sub District. The settlement at Mului can be reached by car for six hours from Balikpapan city. There is a logging road that lies there and connects Mului to the nearest town. The research was conducted for two months (November to December 2005). 


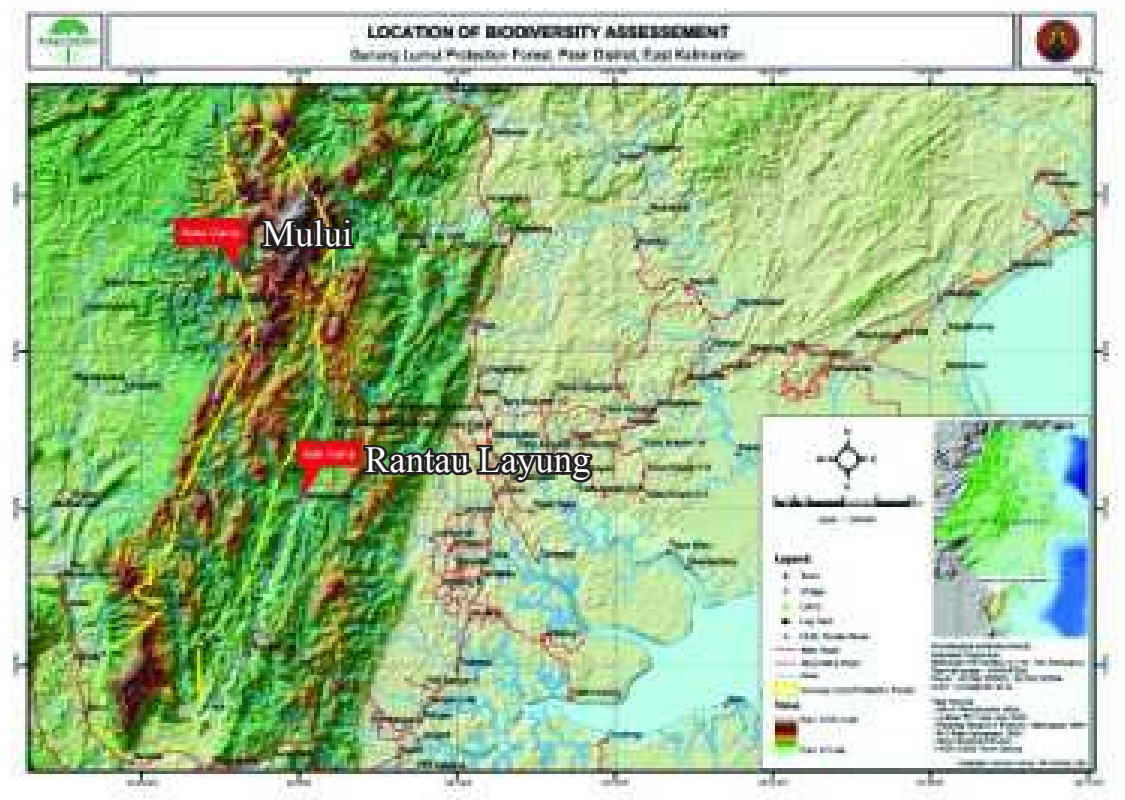

Figure 1. The research location, Mului and Rantau Layung Settlements, located within and around the Gunung Lumut Protection Forest area, Pasir District, East Kalimantan Province (Source: Anonymous, 2005).

\section{B. Data Collection}

There were two types of data collected, i.e. primary and secondary data. The primary data were collected through general observation, focused group discussions (FGD) and personal interviews. General observation was conducted to describe the landscape characteristics and the natural resources before taking place the interviews. The observation was also done to cross check the information collected from the communities. The FGD was carried out basically to obtain general data from various people representing different groups in the community. Personal interviews were supposed to collect detailed information on local perception about forest and conservation, and GLPF legal status as well as household income/expenditures, land ownership, and the usage of natural resources. The methods of data collection were initialized by a community meeting in the each research site.

The secondary data consisted of demography (population related ethnic composition), education level, public facilities, and land use systems. The related 
literatures were collected from several sources e.g. local government, research institutions, and mass media.

\section{Community meeting}

Community meeting in both research sites was attended by most of the community elements in each settlement, comprising young and old people, men and women, and customary leaders. During the meeting, participants were asked to discuss how they recognized land types around them. In both villages, people defined some land types i.e. river, village, rice fields, garden, fallow (young and old), and forest (young and old). In this meeting, four groups of villagers in each research site were proposed to participate in FGD.

\section{Personal interview}

Personal interview was conducted with 15 selected out of 50 households in Rantau Layung and 11 out of 18 households in Mului using semi-structured questionnaires. It took two to three hours for each respondent to fill-out the questionnaires. Discussion focused on local resource utilization e.g. flora and fauna, perspectives on conservation and protection area, and personal expenditure as an approach to have information on local revenue. In addition, the interview was also accomplished with some key-informants both in Rantau Layung and Mului in order to know how people manage their land and natural resources. They included the village head, customary leader, old villagers, and informal community leaders like teacher and ustadz (Islamic teacher).

\section{Focused group discussion}

Four groups of villagers, based on gender and age (old men, old women, young men and young women), were proposed in the community meeting. Each group was composed of five to seven members selected during the meeting. They all participated in focused group discussion facilitated by the researchers (Figure 2). Several topics discussed included specific information about useful natural resources, landscapes, and land uses. 


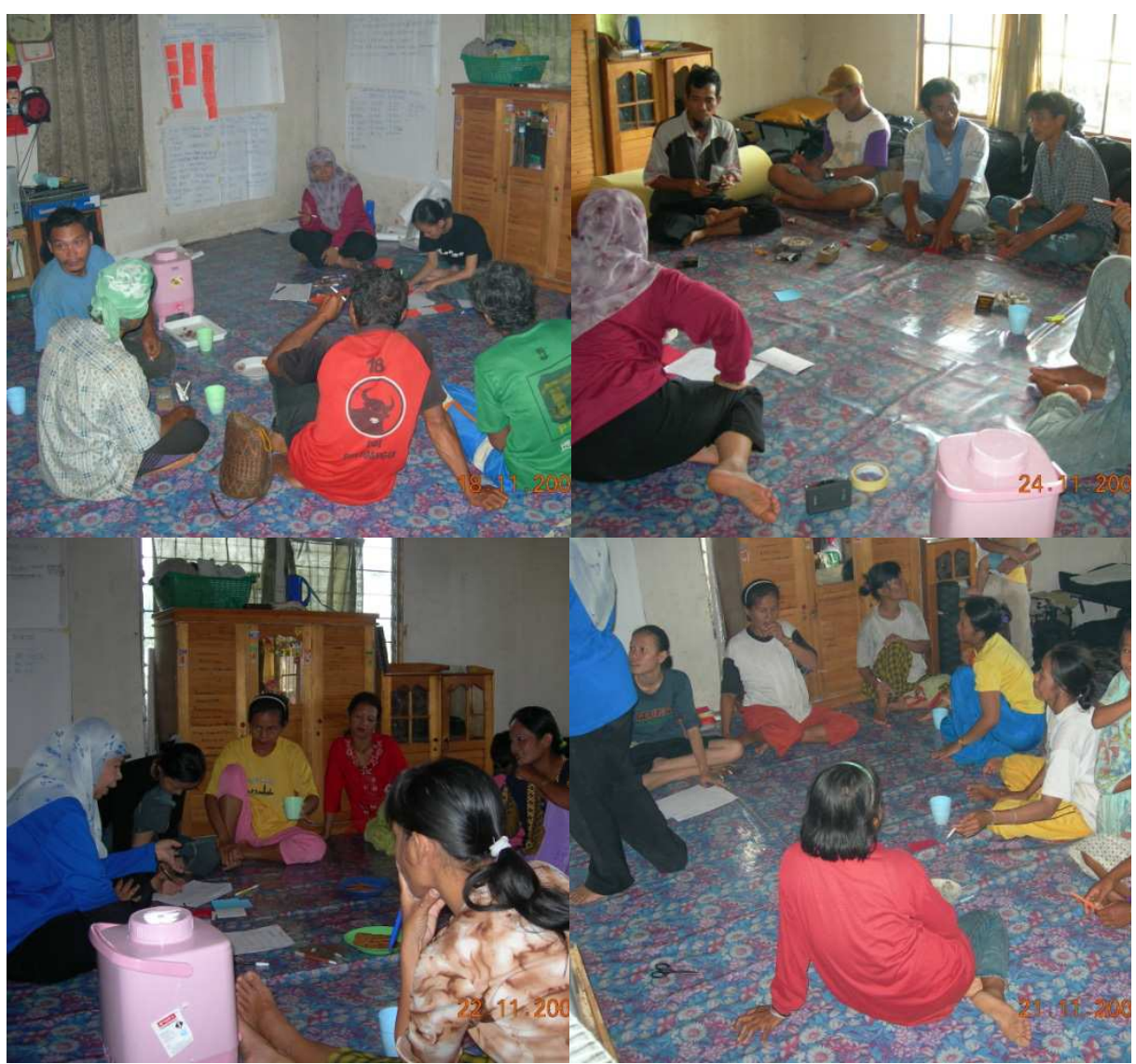

Figure 2. Focused Group Discussion (FGD) activities with men (above) and women (below) group participants.

\section{Data Analysis}

Data on community perception on forest and conservation measured according to the common principles of conservation. Respondents had choices, i.e. 'agree'; 'disagree'; and 'do not know'. The responses were scored as 'correct' (positive perception) if they confirmed conservation principles: i.e. 'agree' for confirming statement and 'disagree' for a contradictory statement. Score one was given to every 'correct' answer, while score zero was to every 'do not know' or 'incorrect' answer. The scored data were then tabulated. The total score was divided by the maximum possible score and expressed as a percentage. The utilization value of forest products (flora and fauna) by the community 
was calculated using the approach of market prices at community level as far as the respondent enable to predict the volume as used and the price per unit.

Household income should be approached through earn generated from both major and minor livelihood. However, this method usually resulted in lower figure since the respondent often revealed lower estimation for their income. Therefore, in this case, household income was approached through household expenditures. The expenditures were classified into three groups, i.e. food, non-food, and production means. If the expenditures were added by saving, we would have an estimated income for each household.

\section{RESULTS AND DISCUSSION}

\section{A. People and Livelihood}

Rantau Layung village is inhabited by 50 households or 217 people with population density reaching about 1 people $/ \mathrm{km}^{2}$ (Desa Rantau Layung, 2005). The dominant ethnic was Paser and most of them were indigenous people. Only 30 villagers have completed their elementary school (SD), 10 villagers have finished secondary school (SMP) and three people have accomplished high school (SMU). The others did not finish elementary school and even some of them never go to school at all. Customary law was still applied in the daily life as traditional guideline and rules to define what is right or wrong for the whole community. Especially in managing natural resources, it was used to classify forest (alas) into categories according to its function i.e. Alas Tuo, Alas Adat, Alas Nareng and Alas Mori. Definitions of these forest categories are explained in the discussion about landscape in the other part of this manuscript. Most of the villagers cultivated upland rice fields by shifting cultivation system for their daily household consumption. They went for hunting and fishing and collecting non timber forest products (NTFP) such as rattan, fruits, vegetables and honey. Communities usually sell these NTFP to Batu Kajang town (capital of Batu Sopang sub District). Another important source of income for households in this village was timber harvest (small-scale logging). From 1995 to June 2005, most of the villagers cut the trees found around the forest area and sometimes even inside the Gunung Lumut Protection Forest. However, after Wana Lestari operation took place in this area in July 2005 to combat illegal logging, the small-scale timber extraction significantly ceased.

In Mului, there are 18 households of 121 peoples, most of them belong to Paser Mului ethnic group (Anonymous, 2002). Children and young people dominate the population. The children just started going to school less than two years ago. Previously, there was no formal school in the area. The older people never went to school except some outsiders who got married with Mului 
people. Separated from the other villagers, Mului people lived inside the area of Gunung Lumut Protection Forest from which they gathered many types of products. Most Mului people cultivated rice field in a small area ( \pm one ha per household) near their houses which provided insufficient yield per year for their consumption. People mixed the rice plant with vegetables plant and fruits trees. It seems that after people have left the area for a new rice field, it will become a fruit garden or agro-forests in the future. They went hunting at least once a month, usually used snare and a few air-rifles. At the same occasion, they collected young sprouts and mushrooms as well for vegetables. Fishes were also important for local source of protein. Selling fruits, animal, and honey was the main source of income for Mului people. Customary rules concerning management of natural resources were still important in Mului.

\section{B. Land Types}

There were several types of landscape in Rantau Layung and Mului where the communities do their daily activities and collect products as sources of revenue. Identified these landscape or land types in Rantau Layung and Mului including their characteristics are described in Table 1. 
Table 1. Identified land types in Rantau Layung and Mului, including their characteristics

\begin{tabular}{|c|c|c|c|c|c|c|}
\hline \multirow{3}{*}{ No } & \multicolumn{3}{|c|}{ Rantau Layung } & \multicolumn{3}{|c|}{ Mului } \\
\hline & \multirow{2}{*}{ Land type } & \multicolumn{2}{|c|}{ Characteristics } & \multirow{2}{*}{ Land type } & \multicolumn{2}{|c|}{ Characteristics } \\
\hline & & Topography & $\begin{array}{l}\text { Main } \\
\text { vegetation }\end{array}$ & & Topography & $\begin{array}{c}\text { Main } \\
\text { vegetation }\end{array}$ \\
\hline 1 & $\begin{array}{l}\text { Umo/Ladang } \\
\text { (Rice field) }\end{array}$ & $\begin{array}{l}\text { flat, gently } \\
\text { slope, steep }\end{array}$ & $\begin{array}{l}\text { paddy, } \\
\text { maize, } \\
\text { rubber, oil } \\
\text { palm }\end{array}$ & Umo (Rice field) & Steep & $\begin{array}{l}\text { paddy, banana, } \\
\text { cassava, } \\
\text { sugarcane, } \\
\text { corn, } \\
\text { vegetables }\end{array}$ \\
\hline 2 & $\begin{array}{l}\text { Strat/Kampong } \\
\text { (Village) }\end{array}$ & flat, undulating & $\begin{array}{l}\text { fruit trees, } \\
\text { coconut }\end{array}$ & $\begin{array}{l}\text { Kampong } \\
\text { (Village) }\end{array}$ & Gentle & $\begin{array}{l}\text { banana, } \\
\text { rambutan, } \\
\text { coconut, } \\
\text { durian, jack } \\
\text { fruit }\end{array}$ \\
\hline 3 & Kebon (Garden) & $\begin{array}{l}\text { flat to steep, } \\
\text { undulating }\end{array}$ & $\begin{array}{l}\text { rubber, } \\
\text { rattan, } \\
\text { coffee, } \\
\text { coconut }\end{array}$ & Kebon (Garden) & flat - steep & $\begin{array}{l}\text { rattan, coffee, } \\
\text { rambutan, } \\
\text { other fruit } \\
\text { trees }\end{array}$ \\
\hline 4 & Lati (Fallow) & $\begin{array}{l}\text { flat to gently } \\
\text { slope }\end{array}$ & $\begin{array}{l}\text { trees of } \\
\text { Peronema, } \\
\text { Vitex, } \\
\text { Arthocarpus, } \\
\text { and bamboo }\end{array}$ & $\begin{array}{l}\text { Lati burok } \\
\text { (Young fallow) }\end{array}$ & Steep & Trees, shrubs \\
\hline 5 & Alas (Forest) & $\begin{array}{l}\text { slope to steep } \\
\text { and undulating }\end{array}$ & $\begin{array}{l}\text { mixture of } \\
\text { dipterocarps } \\
\text { trees }\end{array}$ & $\begin{array}{l}\text { Lati tuo (Old } \\
\text { fallow) }\end{array}$ & Steep & Trees, shrubs \\
\hline 6 & Sunge (River) & $\begin{array}{l}\text { gently slope to } \\
\text { steep }\end{array}$ & $\begin{array}{l}\text { ferns, trees } \\
\text { of Ficus, } \\
\text { Litsea, and } \\
\text { Kleinhovia }\end{array}$ & $\begin{array}{l}\text { Suong bosa } \\
\text { (River/gold mine) }\end{array}$ & Steep & Trees \\
\hline 7 & $\begin{array}{l}\text { Sipung bua } \\
\text { (Fruit garden) }\end{array}$ & Flat to steep & $\begin{array}{l}\text { fruit trees } \\
\text { and rattan }\end{array}$ & $\begin{array}{l}\text { Alas burok } \\
\text { (Young forest) }\end{array}$ & Steep & $\begin{array}{l}\text { trees of Shorea } \\
\text { and Peronema }\end{array}$ \\
\hline 8 & - & - & - & $\begin{array}{l}\text { Alas tuo (Old } \\
\text { forest) }\end{array}$ & Steep & $\begin{array}{l}\text { trees of Shorea, } \\
\text { iron wood } \\
\text { (ulin) }\end{array}$ \\
\hline
\end{tabular}

Seven types of landscape were identified by Rantau Layung community. Cultivation was carried out in dry rice fields (ladang) and garden (kebun) by planting seeds or seedlings with limited input and simple technology. Fruit 
garden (sipung bua) traditionally planted by throwing (spreading) fruit seeds on the field when the ladang is still cultivated. Fallow (lati) was an abandoned rice field, invaded by abundant pioneer plants that can be used as fire wood. In Rantau Layung, forest (alas) was classified into four sub types of landscapes, i.e. Alas Tuo, Alas Adat, Alas Nareng and Alas Mori. Firstly, Alas Tuo is a forest, the usage of which is not yet organized by customary law, located far from the settlement with a steep topography. Secondly, Alas Adat (customary forest) is a forest area, wherein its usage has been organized according to customary law, located far from the village with a steep topography. It can not be exploited and converted to rice fields (ladang). Further, Alas Nareng is a forest reserved for ladang area, located close to the village with gently slope. Lastly, Alas Mori is a forest that is believed to be a dangerous place or haunted area, so that the area can not be utilized.

Trees in customary forest could only be cut down for subsistence or selfusage. When people cut down the tree for income sources (sell the wood), the logger have to contributed to the community through customary leader by paying a kind of tax: Rp. 25,000 per cubic meter $\left(\mathrm{m}^{3}\right)$ for meranti (Shorea spp.) and kapur (Dryobalanops spp.), Rp. 50,000 per $\mathrm{m}^{3}$ for iron wood (Eusideroxylon zwageri), and Rp. 15,000 per $\mathrm{m}^{3}$ for other species. Nowadays, this customary regulation has not been valid anymore since the timber production activity was terminated.

Mului area was surrounded by hills and mountain slopes. People used their land for agriculture, horticulture, and small scale mining activities. There was almost no flat area available for these activities, therefore, rice fields, rattan, and coffee gardens were all developed on the slopes. There were eight land types around Mului settlement recognized by people from there they collected many resources for their daily livelihood (Table 1). Mului people spent time mostly on their agricultural field but most resources were taken from forests. They believed that the surrounding forests were theirs and highly important to support their livelihoods. People divided forest (Alas) landscape into old and young categories. Old forest category means an area dominated by big trees wherein its condition was still relatively intact while young forest refers to an area re-grown or re-planted by some naturally regenerated trees. Suong Bosa was sites along river where people used it to gather gold and fish. Village was defined as the settlement where people live, including home gardens, surrounding their houses. Rice field was a land type where people cultivated paddy mixed with corn, cassava, vegetables, and fruits. Fallow was an abandoned rice field and usually full of small trees and bushes. All landscapes in Mului were mainly characterized with steep topographies, only a few parts of the settlement including home garden and coffee garden were flat or gently sloping. 


\section{Community Perception}

1. Perception on forest and conservation

Local perception on forest and conservation were measured or perceived according to the common principles of conservation. Level of positive perception (correct answer) brought out by communities at Rantau Layung and Mului villages on forest and conservation is presented on Figure 3.

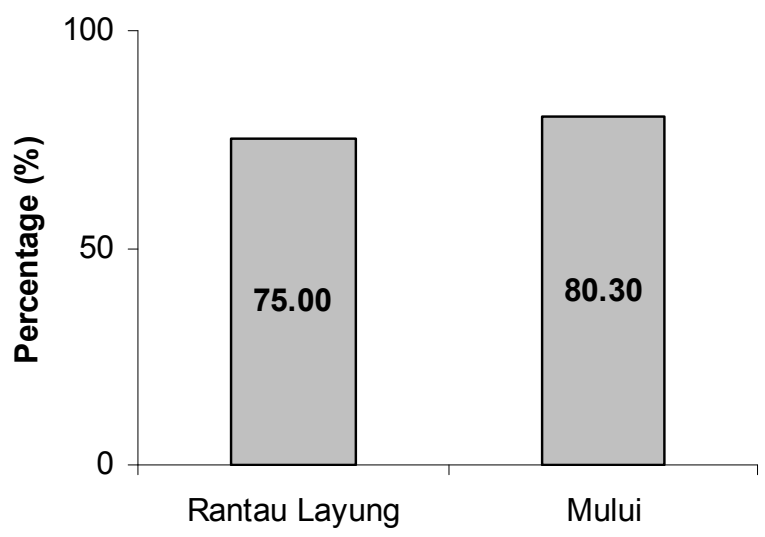

Figure 3. Local positive perception on forest and conservation by communities at two research sites (Rantau Layung and Mului)

In general, the correct or positive perception brought out by local community is high and the difference between two villages is relatively small ( $80.3 \%$ vs. $75 \%$ ). People in Rantau Layung and Mului confirmed that forest provides many resources for their daily livelihood. Therefore, they convinced that forest needs to be conserved.

All (100\%) respondents in Mului and 67\% respondents in Rantau Layung agreed with forest conservation. It was also interesting to note that more than half, $63 \%$ in Mului and 53\% in Rantau Layung, respondents did not think that their hunting activity would lead to animal extinction.

According to all respondents in both villages, investors such as logging and plantation companies had to take local views on important plants and animals into consideration. As many as $82 \%$ respondents in Mului and $60 \%$ in Rantau Layung suggested that most of lands in GLPF were not suitable for permanent and commercial crops including oil palm. In addition, $81 \%$ respondents in Mului and only $47 \%$ respondents in Rantau Layung considered that logging and plantation companies were causing threats for GLPF sustainability. 


\section{Perception on legal status of the Gunung Lumut Protection Forest}

Local knowledge and community perception on the legal status of Gunung Lumut Protection Forest (GLPF) were recorded from the same respondents representing households in Rantau Layung and Mului. In Rantau Layung, only four $(27 \%)$ respondents knew about the decree mentioning Gunung Lumut as a protection forest and only two respondents $(13 \%) \mathrm{knew}$ about borders of the forest. For those who did not know either the decree or the borders, we told them the actual information concerning those issues and asked for their agreement. Most of the respondents (87\%) agreed with the decree and only three respondents (20\%) agreed with the borders. Most respondents could not answer whether or not they agreed with the borders of the protection forest since they did not clearly know where the borders are. In Mului, four respondents (36\%) knew about the decree and nine respondents $(82 \%)$ knew about borders of the forest. Seven respondents $(64 \%)$ agreed with the decree and the border.

By calculating positive responses in each research site and dividing them with the total positive answers of all questions, we obtained relative level of knowledge and perception of the respondent on the legal status of the GLPF (see Figure 4).

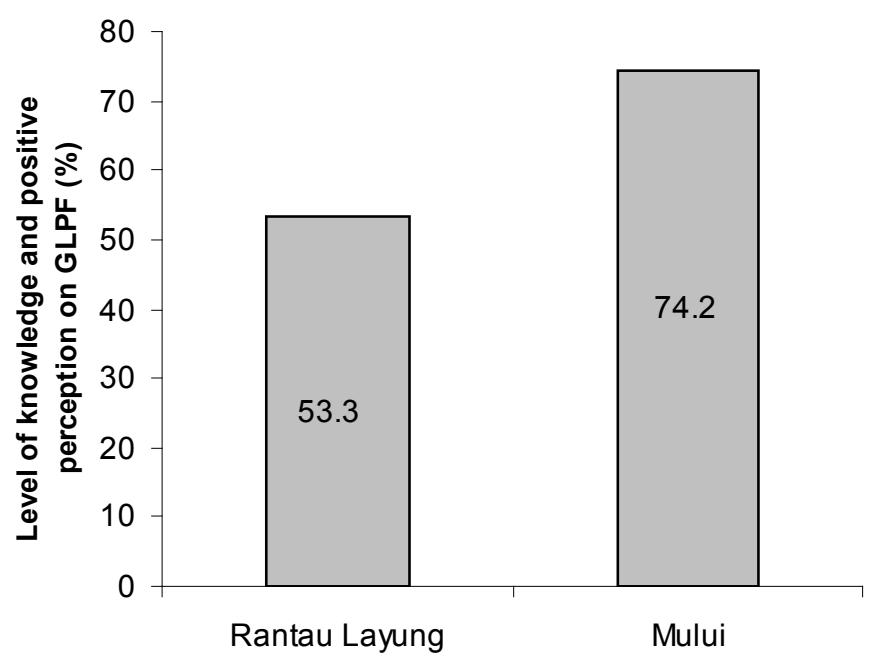

Figure 4. Level of knowledge and positive perception on the GLPF expressed by the community at two research sites (Rantau Layung and Mului) 
Community in Mului had higher knowledge and positive perception on the legal status of GLPF compared with those in Rantau Layung. This might be due to local dependency on nature resources and the accessibility of those two village sites to information from outsiders. Mului people, who live inside the protection area, spent more times in the forest and collect forest products for their daily needs. With their higher dependency on natural resources, they experienced better informal knowledge on the protection forest.

In addition, there was logging road connecting Mului to other places so that villagers had better opportunity to interact with outsiders and improve their knowledge on any issues concerning protection forest. In contrast, Rantau Layung village had very limited access and was connected to outsiders only by a poorly constructed road.

Discussing socialization and/or extension about the legal status of GLPF conducted by related institution, four respondents $(27 \%)$ in Rantau Layung mentioned that they rarely obtained the extension, 11 respondents $(73 \%)$ stated never and none of the respondents got the extension frequently. In Mului, five respondents $(45 \%)$ stated that they got the extension rarely, six respondents $(55 \%)$ answered never and none of the respondents obtained the extension frequently. The description above indicated that the community in Rantau Layung was less reached by the outsider extension worker. Involvement of the both communities in creating the borders for the protection forest was low. There were only three respondents (20\%) in Rantau Layung and one respondent $(9 \%)$ in Mului once involved in the activity.

\section{Natural Resources and Local Utilization}

As the Mului and Rantau Layung settlements are located inside and near the Gunung Lumut Protection Forest, communities in both villages have high dependency on the surrounding forest resources which cover wood and nonwood forest products including animals. The uses of forest resources are direct (home consumption) and indirect (cash earning) which can be calculated using approach to the market prices at community level. In this report, the forest products used by the communities were differentiated into two groups, i.e. flora and fauna.

\section{Resources of flora}

Types of plants used by local community in Rantau Layung and Mului were classified into four groups, i.e. wood, non-wood (rattan, gaharu, bamboo), fruits, and vegetables such as young sprouts of bamboo and fern. Wood is important for some particular uses such as heavy construction including houses, light construction, and fire wood. Especially in Rantau Layung, wood was also used 
as source of income which is usually sold either inside or outside the village during the period of 1995 to the midst of 2005.

Non-wood forest products, particularly rattan and bamboo, were used for light construction and/or furniture/tools and also as a source of household income. Most of forest fruits, such as durian (Durio zibethinus), cempedak (Artocarpus integer) and lei (Durio kutejensis), were sold to the nearest market, i.e. Batu Sopang for Rantau Layung and Swan Slutung for Mului. Vegetables were only used for household consumption in both research sites. Average value of the flora (forest vegetation matters) used by community in Rantau Layung and Mului can be seen in Table 2.

Table 2. Average value of the forest flora (vegetation matters) used by community in Rantau Layung and Mului

\begin{tabular}{lcccccc}
\hline & \multicolumn{5}{c}{ Average value of flora (vegetation matters) used per } \\
household per year
\end{tabular}

Note: $\mathrm{n}=$ number of respondent

Community in Mului did not sell wood from the forest, they mainly used wood for cooking (fire wood). Beside, they also used wood for maintaining their houses. Their houses were built by the District Social Services in 1999 when the sub village was established as a resettlement area. Therefore, they used small volume of wood for light construction including hut in their fields. Communities in both settlement areas also consumed vegetables gathered from the forest.

The most valuable product of plants used by the community in both villages was fruits. Mului people consumed more forest fruits and recognized more plant species than people in Rantau Layung. This may be influenced by the accessibility in Mului village which was easier to market their non-wood forest products than that in Rantau Layung village. Location of the settlement which was inside the forest area also contributes to the more non-wood forest product gathered by the Mului community. 
Apart from those marketable resources of forest plants gathered by the community in Rantau Layung and Mului, there were other important utilizations (though people never consider them to sell and buy) such as traditional medicine, tools, basketry, ornament/ritual, hunting place, and hunting tools. Complete description of those useful plants in detail including species, category of use, habitat preference, parts being used, and availability in the nature is very important for the plants species conservation. Habitat of certain species was reflected by the specific place where the species gathered by the community. The availability of important plants was influenced by method of harvesting, regeneration as well as growth rate of the species. Destructive way in harvesting of certain fruit bearing trees, for instance by cutting down the branch and even the tree, will decrease the species population.

There were 104 identified species of plants (from the total of 126) widely used by community in Rantau Layung. It consisted of $\mathbf{4 4}$ family and 6 types of flora (tree, climber, palm/bamboo, shrub, herb, and fungi). The family of Palmae had the highest number of species ( 20 species) used by the community, followed by Moraceae ( 10 species) and Leguminosae $(7$ species). The plants were used mostly for food, medicine and construction including heavy, light, and boat constructions, either for subsistence or for commercial uses (as source of income). Parts of the plants as most frequently used were stem, fruit and root. It was noted that many species had two or more useful parts, for example walor or Nauclea subdita (the root, the bark, the leaves, and the sap).

Data on the dynamic availability of the useful plants indicates that population of several species which tended to decrease were bekokal (Saraca declinata), gaharu (Aquilaria malaccensis), kapur/sintuk (Dryobalanops lanceolata), keramu (Dacryodes rostrata), keranji (Dialium spp.), perari (Neolitsea $s p$.$) , and ulin (Eusideroxylon zwageri). Decrease in the population of gaharu and$ keranji was closely related to the local harvesting system. So far, a traditional way in collecting gaharu/eagle wood was by cutting down the stump whenever people find the tree since none of them knows exactly which tree contains the gaharu. Fruits of keranji are small and abundant so the villagers usually cut the tree to make fruit gathering easier. However, the villagers were aware of that impact and tried to stop the destructive harvesting method through customary regulation. It was said that when someone was cutting the keranji tree, he or she has to share $50 \%$ of the yield with the community through customary leader. If it happens for the second occasion, two third (2/3) of the yield has to be given to the community and for the third occasion, the customary leader will take them all away.

There were many species of plants identified and used by Mului people. Most of them were edible and the others were used for medicine, construction, hunting tools, cash income, etc. Many of them have more than one category of 
use for local people. Overall, it was recorded that 511 plants species were used in daily Mului people life. In this research, as many as 162 out of all recognized plants were collected and identified. People collected those plants mainly from the forest while a few were collected from home garden, agricultural field, rattan garden, and bushes.

Availability of the flora used by Mului people was reported as numerous for most species. There were only some species of flora found in small number of population in periods of past, present, and future. Bamboo, jombu (a kind of tree) and luyan (a kind of climber), for example, were reported as decreasing recently. In addition, local people believed that the number of new domesticated species of flora, e.g. rattan and bamboo would increase.

\section{Resources of fauna}

Forest animals or their products utilized by community in Rantau Layung and Mului villages can be distinguished into four categories, i.e. mammal, bird, fish and others (mainly honey as a product of bees). Species of mammals frequently utilized by most villagers were rusa (Cervus unicolor), kijang (Muntiacus muntjak), kancil (Tragulus napu), and trenggiling (Manis javanica), while species of birds covered ayam butan (Lophura ignita), lembukon (Chalcophaps indica), merak (Argusianus argus), and lensio (Rollulus rouloul). River fishes were gathered by most villagers in Rantau Layung since the settlement area is very close to the river. Some species of mammals, birds, and honey were used for daily household consumption and some others were sold to the nearest market as a source of household income. Most of fishes were only used for food and rarely sold. Average value of fauna (animal -related matters) used by community in Rantau Layung and Mului can be seen in Table 3.

Table 3. Average value of the forest fauna (animal - related matters) used by community in Rantau Layung and Mului

\begin{tabular}{|c|c|c|c|c|c|c|c|c|c|}
\hline \multirow[b]{3}{*}{ Community } & \multicolumn{8}{|c|}{$\begin{array}{c}\text { Average value of fauna (animal-related matters) used per household per } \\
\text { year }\end{array}$} & \multirow{3}{*}{$\begin{array}{l}\text { Total } \\
\text { (xRp. } \\
1000)\end{array}$} \\
\hline & \multicolumn{2}{|c|}{ Mammal } & \multicolumn{2}{|c|}{ bird } & \multicolumn{2}{|c|}{ fish } & \multicolumn{2}{|c|}{ honey } & \\
\hline & $\begin{array}{l}\text { Volu- } \\
\text { me } \\
\text { (ind.) }\end{array}$ & $\begin{array}{l}\text { Value } \\
\text { (xRp. } \\
1000 \text { ) }\end{array}$ & $\begin{array}{l}\text { Volu- } \\
\text { me } \\
\text { (ind.) }\end{array}$ & $\begin{array}{l}\text { Value } \\
\text { (xRp. } \\
1000 \text { ) }\end{array}$ & $\begin{array}{l}\text { Volu- } \\
\text { me (kg) }\end{array}$ & $\begin{array}{l}\text { Value } \\
\text { (xRp. } \\
1000 \text { ) }\end{array}$ & $\begin{array}{l}\text { Volu- } \\
\text { me (L) }\end{array}$ & $\begin{array}{l}\text { Value } \\
\text { (xRp. } \\
1000 \text { ) }\end{array}$ & \\
\hline $\begin{array}{l}\text { Rantau Layung } \\
(\mathrm{n}=15)\end{array}$ & 5.6 & $1,105.3$ & 1.3 & 37.6 & 180.3 & 786.9 & 21.2 & 828 & $2,619.2$ \\
\hline Mului (n=11) & 10 & 573.8 & 30.5 & 943.5 & 141.5 & 367.9 & 0.45 & 22.7 & $1,902.4$ \\
\hline
\end{tabular}

Note: $:$ ind. $=$ individuals 
Most people in Mului were skillful hunters and they caught more mammals and birds than Rantau Layung people. Each household used 10 individual mammals and 30.5 birds in average per year or almost one mammal and 2.5 birds per month. Again, this could be understood as the Mului people are living inside the protection forest area so that they could easily got access to animal resource. However, they only collected honey approximately five liters in a year, which was much lower than that collected by Rantau Layung people.

Apart from those marketable resources of forest animals gathered by the community in Rantau Layung and Mului, there were other important utilizations (though people never consider them to sell) such as traditional medicine, rifle, and ornament/ritual. Identification of those useful animals in details including species, uses, parts being used, the way of catching, and availability in nature is very important as a point in developing and/or conserving the animal species. Preference site to stay for certain species was correlated with the animal habits and reflected by specific place where the animals were often caught by the community. The important animal availability is influenced by method and number of harvesting and breeding rate of the species. Over catching of forest animals will lead to decrease in the species population.

Data on dynamic availability of several animals in Rantau Layung shows that they tended to decrease in the coming years. Some local people mentioned that fish population in Kasunge River was decreasing compared to that of 10 years ago and it is even going to be less available in the future. This may be affected by the harvesting method people used such as net and electric fish catcher which catches fish from the whole size including the small ones. Honey production was also reported to decrease compared to that of 10 years ago and it will continue decreasing. Production of honey is related to the availability of flowerbearing trees as sources of bee-forage which is influenced by logging activity. In the period of 2001 to 2003, there was a small-scale concession (IUPHHK) around Rantau Layung village. In addition, logging activities conducted by local people in Rantau Layung during 1995 to 2005 also contributed to the decrease of population of flower-bearing trees. Other animal species with their population were reported to decrease were kancil/mouse deer (Tragulus sp.) and rusa/sambar deer (Cervus unicolor).

People in Mului identified 90 animal species used in their livelihood. They were mostly birds and mammals although reptiles and fishes were also recorded. People consumed most of them except reptiles, and sold big mammals such as rusa (Cervus unicolor) and birds e.g. tiung (Gracula religiosa). Some animals were used as ornament e.g. binturung (Arctictis binturong) and medicine e.g. beruang madu/sun bear (Helarctos malayanus) and kalong (bats). 
Mului villagers hunted mammals, birds and reptiles in the forest, specifically in salt springs, and shrubs near their settlement. Fish and mollusk were caught in Suong Bosa and Mului Rivers. Specific animal such as bats was collected in few caves of Mount Tekedey.

The fact, as previously described, that Mului people were good hunters and they lived inside GLPF should be taken into consideration in the management of GLPF. People should be aware that there are many animal species which are endangered and protected by Indonesian law. Particular species such as sun bears (Helarctos malayanus) is an example of the endangered animals (Saleh, 2003) but at the same time remain important for livelihood in Mului.

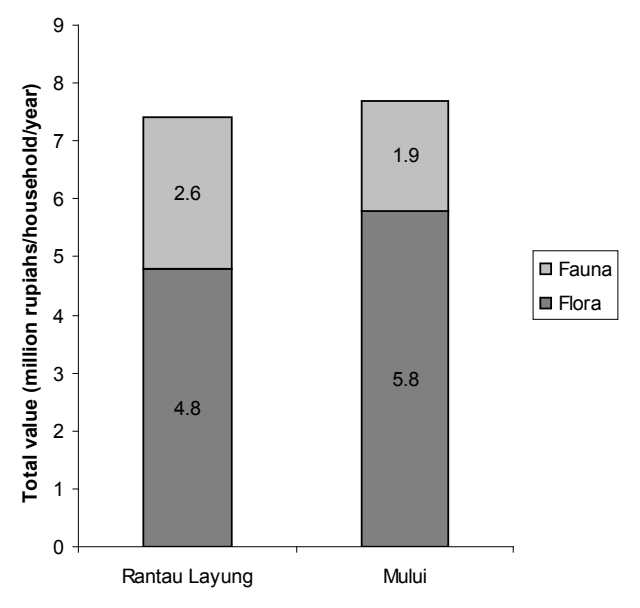

Figure 5. Total value of flora and fauna utilized by the communities in Rantau Layung and Mului per household per year

Total value of flora (vegetation matters) and fauna (animal-related matters) utilized by communities in Rantau Layung and Mului per household per year is presented in Figure 5. It indicates that Rantau Layung people living around Gunung Lumut Protection Forest collected forest resource valued as much as Rp. 7.4 million rupiahs per household per year. It is lower, although the difference is not significant, than those in Mului (7.7 million rupiahs) where people are living inside the protection forest. In both settlements, the value of flora used by the community was higher than the value of fauna (two to three times). These amounts were considered as economic contribution of forest resources (particularly Gunung Lumut resources) to the local community. The contribution did not include intangible benefit yet such as clean water and fresh air useful for the community for their daily life. These benefits of Gunung Lumut Protection Forest should be taken into account by a policy 
maker in managing the area. If the area is damaged and the forest becomes degraded, some important uses will be diminished and the community and/or the local government have to look for other sources to substitute for the lost benefit. Categories of uses of flora and fauna by community in Rantau Layung and Mului including number of useful fauna by each category are described in Table 4.

Table 4. Categories of uses of natural resource by community in Rantau Layung and Mului, including number of useful flora and fauna by each category

\begin{tabular}{lcclcc}
\hline \multicolumn{3}{c}{ Rantau Layung } & & \multicolumn{3}{c}{ Mului } \\
\hline Category of uses & $\begin{array}{c}\text { Number } \\
\text { of flora }\end{array}$ & $\begin{array}{c}\text { Number } \\
\text { of fauna }\end{array}$ & Category of uses & $\begin{array}{c}\text { Number } \\
\text { of flora }\end{array}$ & $\begin{array}{c}\text { Number } \\
\text { of fauna }\end{array}$ \\
\hline Food & 44 & 14 & Food & 133 & 59 \\
Medicine & 26 & 5 & Medicine & 37 & 14 \\
Light construction & 16 & - & Light construction & 23 & - \\
Heavy construction & 22 & - & Heavy construction & 14 & - \\
Boat construction & 9 & - & Bike construction & 5 & - \\
Firewood & 4 & - & Firewood & 26 & - \\
Basketry & 7 & - & Basketry & 15 & - \\
Ornament/Ritual & 5 & 7 & Ornament & 37 & 21 \\
Hunting place & 8 & - & Hunting place & 14 & - \\
Hunting tools & 4 & - & Hunting tools & 23 & - \\
Tools & 12 & 3 & Tools & 18 & 2 \\
Source of income & 27 & 14 & Source of income & 29 & 25 \\
\hline
\end{tabular}

\section{E. Household Income and Expenditure Pattern}

Average household expenditures, saving, and estimated income of community at Rantau Layung and Mului are described in Table 5. In general, household expenditures in Rantau Layung village were significantly higher than those in Mului sub village. However, households in Mului saved their money much higher than those in Rantau Layung. This indicated that households in Rantau Layung more consumptive than in Mului. For both communities, food was the highest expenditure, while production means was the lowest expenditure. Even in Mului, expenditure for production means was less than for 
saving. It explains that the shifting cultivation system carried out in those two areas uses very low input. They never buy, for example, good quality seeds or seedlings, fertilizer and/or pesticide except a small volume of herbicide. Natural fertility of forest land was the dominant input for their agricultural crops.

Table 5. Household expenditures, saving and an estimated income (mean value) per year

\begin{tabular}{|c|c|c|c|c|c|}
\hline \multirow{2}{*}{ Community } & \multicolumn{3}{|c|}{ Expenditures (Rp./year) } & \multirow{2}{*}{$\begin{array}{c}\text { Saving (Rp./ } \\
\text { year) }\end{array}$} & \multirow{2}{*}{$\begin{array}{l}\text { Estimated } \\
\text { income } \\
\text { (Rp./year) }\end{array}$} \\
\hline & Food & Non-food & $\begin{array}{c}\text { Production } \\
\text { means }\end{array}$ & & \\
\hline $\begin{array}{l}\text { Rantau Layung } \\
(\mathrm{n}=14)\end{array}$ & $6,040,854$ & $5,248,185$ & 289,538 & 273,846 & $11,852,423$ \\
\hline Mului $(\mathrm{n}=11)$ & $3,715,164$ & $2,487,295$ & 34,091 & 472,727 & $6,709,277$ \\
\hline
\end{tabular}

Comparison between expenditures for food and for non-food by those two communities was quite similar. People spent their money to buy non-food necessities a bit less than a number of money for food. So, they have considered and allocated a proportional amount of money to buy clothes, medicines, tolls, etc.

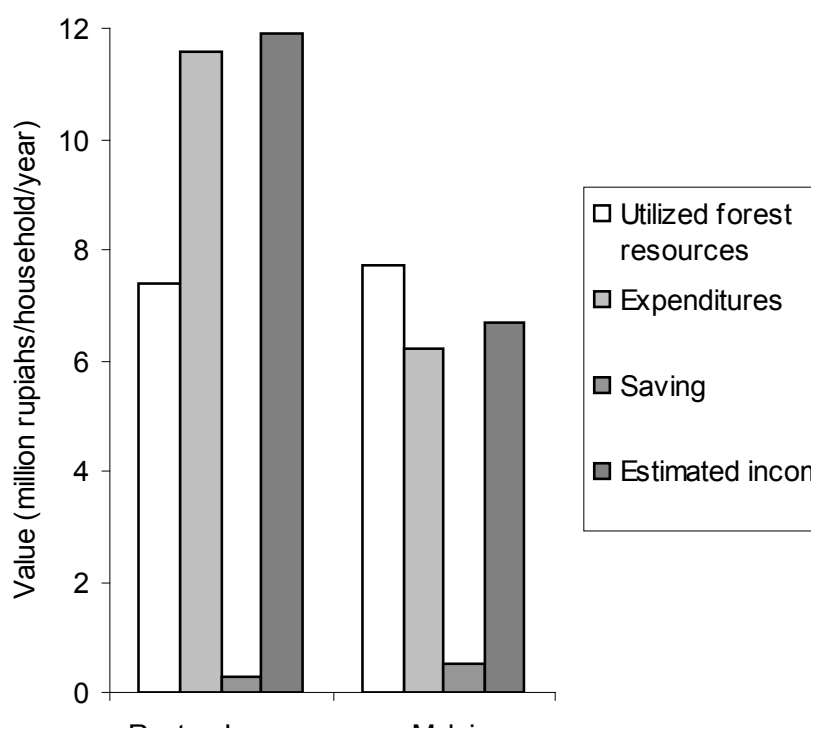

Figure 6. Comparison between values of forest product utilized and estimated income of communities in Rantau Layung and Mului sites 
The two communities generated their cash income mostly from selling forest products mainly non-wood forest products. In Rantau Layung, community's cash income was much higher than the value of total forest product gathered, while in Mului it was slightly fewer (see Figure 6). Although the total value of forest product gathered by those communities comprises direct (the material used directly) and indirect used (the material sold for cash income), this figure shows that community in Rantau Layung has other important sources of income such as rattan, rubber and timber.

Table 5 shows that estimated community incomes in Rantau Layung and Mului are 11.85 and 6.71 million rupiahs per household per year, respectively. Each household in Rantau Layung and Mului consisted of approximately four and six people so that we can assume the average income per capita was 2.96 million rupiahs for Rantau Layung people and 1.12 million rupiahs for Mului people. The income per capita was lower than GDRP (Gross Domestic Regional Product) per capita of Pasir District 2004 based on a constant price as much as Rp. 4.5 million. It was much lower than GDRP per capita of Pasir District based on a valid price, i.e. Rp. 13.1 million (BPS Kabupaten Pasir, 2004).

An alternative way to improve these low community incomes in both Rantau Layung and Mului is by creating an added value of non timber forest products (NTFP) such as fruits, rattan and honey. Added value of those NTFP will be gained through application of post harvesting technologies. The raw materials should be processed into a half or a ready made good. Rattan can be made and sold as mats while honey should be sold in a desired packet. Durian and lei, for example, should be processed into lempo and sold it in a nice packet. To realize this matter, the local communities need a specific training to improve their skill. Sardjono, et al. (2005) also suggest to improve the NTFP gathering method and to develop the post harvesting technology.

\section{F. Threats and Opportunities to the GLPF}

The GLPF provides many benefits for both surrounding communities and outsiders, either tangible or intangible. To guarantee the sustainability of the benefits, the conservation area has to be maintained. In order to manage the GLPF in a sustainable manner, actual and potential threats as well as opportunities to the condition of the conservation area need to be identified.

1. Threats

Several big concessions (HPH: Hak Pengusabaan Hutan) around the GLPF could be considered as a potential threat to the sustainability of the protection area. Past experiences showed that many HPHs operated out of their concessions 
and the neighboring areas became their target. If the existing HPHs are not properly controlled, illegal logging by the HPHs will occur in the GLPF.

Small-scale logging, either by local community or by outsider was another threat to the protection area. As an example, small-scale logging had been conducted by Rantau Layung community during the period of 1995 to mid of 2005 with the capacity of 8 to 12 cubic meters per team a month (there were about 20 teams). Assuming the logging operated for 10 months in a year, the amount of wood gathered would be 2,000 cubic meter per year. If volume of one tree is equivalent to four cubic meter of wood, then 500 trees had been cut down in a year or 5,000 trees in 10 years. With more villages around the GLPF carrying out the same activity, then the negative impact to resources will be more significant and the GLPF management should take this into account.

Shifting cultivation practices is a traditional agriculture system that would be sustainable as long as growth of population is low to limit clearance of forested area for rice field. However, high population growth in villages around the GLPF will increase local need for agricultural land. This will subsequently lead to forest clearing. The GLPF will possibly be utilized when no more forests outside the protection area is available for this traditional agriculture.

Boom of oil palm plantation in East Kalimantan reached around the GLPF. Most villagers in Rantau Layung and probably communities in other villages around the GLPF were eager to develop oil palm plantation. In the case of Rantau Layung community, some people proposed to develop oil palm plantation to Estate Crop District Services. So far they agreed, but Forestry District Services did not, since the area is close to the GLPF and classified into forestry plantation area (Kawasan Budidaya Kehutanan). However, the community continued trying to establish this commercial estate crop plantation. Once the plantation exists around the GLPF, it will extend fast and most possibly encroach into the protection area.

Hunting activities was one important source of income for communities in the research sites. There was no control for hunting activity which has been applied either within or around the GLPF. Since there were many endangered species living in and around the GLPF, implementation of the hunting regulation in the area is a must.

A few people in research sites had knowledge on the GLPF borders and most of them believed that the forest next to settlement was their customary land. Lack of knowledge on status and the role of people living inside the GLPF may cause conflicts among stakeholders and thus will disturb the forests.

Logging road is an important access to outside area for local people, but it could be potentially harmful for the GLPF. The road crossing over the 
protection forest, and connecting Swan Slutung village to the main road created open access to the GLPF, from which anyone including outsiders could easily extract forest resources. The use of this logging road should be well monitored in order to minimize the forest disturbances.

\section{Opportunities}

There were some customary rules closely related to conservation, in which people in both villages still follow. In Rantau Layung, for example, people recognized one forest category i.e. Alas Mori which was believed as sacred area since ancient spirits still remain. Nobody may disturb this area otherwise they would get punishment, e.g. getting sick. In Mului, people were prohibited to cut and sell trees. It was only allowed for small construction (house repairing, etc.). These local wisdoms need to be maintained and can be integrated into the management plan of the protection area.

Natural resources in Rantau Layung and Mului were potentially high from which some alternatives of livelihoods can be developed to support local source of income. Apart from rattan, some people in Rantau Layung were trying to establish rubber plantation in their garden. Some others were collecting and selling honey in traditional ways. Local government and other related institutions should take these into their account by training local people to increase the added value of their products.

In addition, customary leader in Rantau Layung suggested that a potential spring water near the mouth of Prayan River can be developed, if there are any helps, to provide clean and clear water for local people. In Mului, natural resources and local culture may be improved into ecotourism activities.

\section{CONCLUSIONS AND RECOMMENDATIONS}

\section{A. Conclusions}

1. Mului settlement was located inside the Gunung Lumut Protection Forest (GLPF) and more accessible than Rantau Layung village which is outside the protection area. Education level of both communities was very low. Most people did not accomplish elementary school yet or even never went to school at all.

2. Seven and eight landscape types were identified by Rantau Layung and Mului people, respectively in their settlements, from which they derived many resources. 
3. Mului people, who lived inside the GLPF, had higher positive perception on forest and conservation as well as on legal status of the GLPF compared to Rantau Layung people, who lived outside the protection area.

4. Extension on utilization and conservation of natural resources in both research sites was rarely undertaken. Communities' involvement in forest management was low.

5. Economic contribution of the GLPF resources, mainly non timber forest products, to the local livelihoods was significant, i.e. seven to eight millions rupiah per household per year. Plant resources contributed two to three times higher than animal resources.

6. Most non timber forest products gathered from forest were sold as raw materials. No post harvesting technology had been applied to gain an added value of the products.

7. Estimated income per capita of Rantau Layung and Mului people were 2.96 and 1.12 millions rupiah, respectively. It was much less than Gross Domestic Regional Product per capita of Pasir Regency.

8. More than $50 \%$ of expenditures by Rantau Layung and Mului people were allocated for food, while investment for production means was only $1.5 \%$ of the total expenditure. Shifting cultivation in those two settlements was managed with very low input and there was almost no technology applied.

9. Several potential threats to sustain the GLPF were identified, i.e. existing big concessions (HPHs) around the protection area, small-scale logging activities, boom of oil palm plantation, and shifting cultivation practices as well as hunting activities.

10. Natural resources in Rantau Layung and Mului such as plants and animals resources including culture and local wisdom can be potentially developed to support local livelihoods.

\section{B. Recommendations}

1. To improve accessibility to Rantau Layung village and increase knowledge of Rantau Layung and Mului people, it is necessary to develop infrastructure facilities covering road, education, and health facilities.

2. Extensions on utilization and conservation of natural resources as well as public awareness on the Gunung Lumut Protection Forest (GLPF), in both research sites need to be implemented.

3. To gain an added value of non timber forest product gathered by communities in Rantau Layung and Mului, it is necessary to introduce post harvesting technologies and packing systems. 
4. Community-based forest management should be properly implemented. The GLPF management should increase community involvement in their planning and activities

5. Socialization to local people on the GLPF border and status should be more intensified to reduce conflicts.

6. To increase agriculture yields, farming system need to be improved: more input have to be invested and suitable technology should be implemented.

7. Several possible potential threats to sustainability of the GLPF should be minimized and controlled. All the GLPF related stakeholders should recognize and implement the regional spatial planning of Pasir District in accordance with Forest Land Use Agreement (Tata Guna Hutan Kesepakatan).

\section{REFERENCES}

Anonymous, 2002. Profil Desa Swan Selutung, Kecamatan Muara Komam, Kabupaten Pasir, Kalimantan Timur. Departemen Dalam Negeri Republik Indonesia

Anonymous. 2005. Proposal of Gunung Lumut Biodiversity Assessment. Loka Litbang Satwa Primata in cooperation with TBI Indonesia Programme. Balikpapan.

BPS Kabupaten Pasir. 2004. Kabupaten Pasir dalam angka tahun 2004. Badan Pusat Statistik Kabupaten Pasir.

Desa Rantau Layung. 2005. Daftar Isian Potensi Desa tahun 2005. Desa Rantau Layung. Pemerintah Kecamatan Batu Sopang.

Saleh, Chairul. 2003. Panduan Identifikasi Jenis-jenis Satwa Dilindungi di Indonesia. Wildlife World Fund - Perlindungan Hutan dan Konservasi Alam. Jakarta.

Saragih, B. 2004. Nilai ekonomi kawasan hutan lindung gunung Lumut bagi masyarakat dan pemerintah Kabupaten Pasir. A paper presented in Tropenbos Workshop in Balikpapan.

Sardjono, M.A., S. Soedirman, I. Kuncoro, Rujehan and Kamaruddin. 2005. Para pihak kehutanan di Kalimantan. Analisis permasalahan dan kebutuhan.

Kerjasama Tropenbos Indonesia dengan Kelompok Kajian Kebijakan Pembangunan Kehutanan.

UPTD Planologi Kehutanan Balikpapan. 2004. Laporan risalah sebagian hutan lindung Gunung Lumut. Dinas Kehutanan Propinsi Kalimantan Timur. Balikpapan 
